\title{
Protein Tob2
}

National Cancer Institute

\section{Source}

National Cancer Institute. Protein Tob2. NCI Thesaurus. Code C104698.

Protein Tob2 (344 aa, $37 \mathrm{kDa}$ ) is encoded by the human TOB2 gene. This protein plays a role in cell cycle arrest. 